\title{
Using System Dynamics to Analyze the Leadership Style on Motivation and Soldier's Performance
}

\author{
Bambang Suharjo ${ }^{1, *}$ \\ ${ }^{1}$ Master Program of System Analysis and Operation Research, Sekolah Tinggi Teknologi Angkatan Laut - Indonesia
}

\begin{abstract}
In order to carry out the main tasks of the Military to safeguard the sovereignty of the nation and the state, the educated, trained and professional soldiers are needed. Therefore, it is necessary to continuously improve work motivation and performance of all soldiers. The research was carried out on 200 Personnels at military education institutions to obtain data on relationships between variables. The data was processed with the structural equation model and was continued with system dynamics to obtain simulations that reflect the relationship model between variables. Based on the compiled system dynamics model, the conclusions and suggestions for improvement leadership style and motivation in order to improve the soldier's performance can be obtained. The results showed that: system dynamics can be used to model soldier's performance. It was needed to increase the transformational leadership style and transactional leadership style and motivation in order to improve the performance of soldiers. Some efforts can be made to improve performance through leadership styles such as reward and punishment and encourage innovation, creativity, and inspiration from leaders.
\end{abstract}

Keywords: system dynamics; leadership style; motivation; performance; soldier.

\section{Introduction}

\subsection{Background}

In order to carry out the basic tasks of the Indonesian Military (TNI), it is needed to have educated, trained and professional TNI soldiers starting from TNI education institutions capable of carrying out this task. Therefore, it is necessary to continuously improve the work motivation and performance of all soldiers serving in the TNI Educational Institution.

Based on interviews conducted with the personnel of the TNI educational institution personnel, it can be concluded that the performance of the personnel of the TNI education institution is not optimal. This was indicated by the presence of personnel who completed work beyond the targeted time, and there was still personnel during working hours who did not use their time optimally to work so that performance achievement was based on low-performance time at the beginning of the year and soared at the end of the year. The same thing was also stated by the planning staff at the TNI education institution, that there was still work piling up at the end of the time period, indicating the need to improve the performance of TNI Education Institution personnel in general, although in the end it could be resolved.

The results of interviews with previous studies, said the staff of the TNI Educational Institution Personnel, showed that members' work motivation was still necessary and could be improved. This can be seen in not many proposals to improve work performance and new innovations in improving better work efforts and strive to complete work with better results and a faster process to achieve organizational goals. Many members who still work according to standards, have not sought better work results.

On the other hand, based on the theory and results of research on transformational leadership style, transactional leadership style, motivation and performance and the relationship between transformational leadership style, transactional leadership style, motivation, and performance there is a relationship that allows modeling to be carried out.

First, there is the influence of transformational and transactional leadership styles on performance [1-4]. Second, the influence of transformational leadership style and transactional leadership style on work motivation [5-7]. The third is the positive influence of motivation on performance [8-10]. Fourth, there is a positive influence given by transformational and transactional leadership styles and motivation on performance based on the theory developed by Luthans $[11]$ and researched by $[12,13]$. The results of this study indicate that work motivation is a variable that influences the performance of personnel in an organization. Besides that motivation is very likely influenced by transformational and transactional leadership styles. Next, the performance of personnel in an organization is influenced by transformational and transactional leadership styles. Thus, to improve the

\footnotetext{
* Corresponding author: bambangs005@yahoo.com
} 
performance of personnel it is possible to do this through increasing motivation and improving the transformational leadership style and transactional leadership style of the organization.

Referring to the current conditions as presented in the results of preliminary research at the TNI Educational Institution which states the need to increase the motivation and performance of soldiers in the TNI Education Institution, supported by theory and previous research that transformational leadership style and transactional leadership style positively influence motivation and the performance of personnel in the organization, it is possible to research how the influence of transformational leadership style and transactional leadership style on the motivation and performance of soldiers within the TNI Educational Institution.

\subsection{Problems}

Based on the background, problems can be formulated in this study, namely how the influence of transformational and transactional leadership style on the motivation and performance of TNI Education Institution personnel using system dynamics.

\section{Literature Review}

\subsection{Dynamics Systems and Structural Equation Models (SEM)}

System dynamics is a methodology and mathematical modeling technique to frame, understand, and discuss complex issues and problems. Originally developed in the 1950 s to help corporate managers improve their understanding of industrial processes, SD is currently being used throughout the public and private sector for policy analysis and design [14]. System dynamics can be used to carry out simulations in order to analyze and conduct forecasting on problems in the fields of economy, population, engineering, psychology and so on. System dynamics is widely applied in the field of operations management including human resource management [15].

While structural equation modeling (SEM) is a multivariate statistical framework that is used to model complex relationships between directly and indirectly (latent) observed variables. SEM is a general framework that involves solving a system of linear equations simultaneously and includes other techniques such as regression, factor analysis, path analysis, and modeling of latent growth curves [16].

In this research, we merged SEM with system dynamics to forecast the performance variable when motivation and leadership style variables were got. The major advantage of system dynamics over traditional forecasting methods [17]. The advantage includes that system dynamics models are more reliable than statistical models and allow us to estimate the sensitivity of results to variables and employ stronger scenarios accordingly.
The merging of System dynamics with the output equation of SEM is an attempt to carry out modeling simulations that have been produced with SEM on a system that can fully explain the output that is expected to obtain certain values of endogenous variables analyzing and forecasting expected achievements. Thus a strategy can be drawn up to get the full results.

\subsection{Performance}

Performance is an activity related to the work expected of a person and how well the activity is carried out as an achievement or work quality and the quantity that has been achieved in accordance with the implementation of the functions, duties, and responsibilities of his work to the organization in accordance with the applicable rules in the organization $[18,19]$. Furthermore, performance can be explained in various dimensions. Performance including quantity, quality, timeliness, effectiveness, and presence [20]. While the way of measuring performance is including quantity, quality, and timeliness [8]. Thus in this study, performance can be explained from the dimensions of quantity, quality, timeliness, effectiveness, and presence.

\subsection{Motivation}

Some experts define motivation as a force that drives direction, level of effort and level of the perseverance of someone to achieve the desired goal [21-23]. Furthermore, the dimensions of motivation, namely the processes that account for individual's intensity, direction, and persistence of effort toward attaining a goal [24]. The three key elements of the definition of Robbins and Judge are intensity, direction, and hard work. By referring to the above view, the notion of motivation is the power that drives direction, level of effort and level of the perseverance of a person to achieve the desired goal. The elements of motivation are in the form of intensity, direction, and hard work.

\subsection{Leadership Style}

Leadership is a process of social influence from someone who gives influence to others and inspires, motivates, and directs their activities to carry out tasks in order to help achieve group or organizational goals [2, 25]. Further explained that leadership styles are grouped into two, namely the transformational leadership style and transactional leadership style [26].

Transformational Leadership is a process affecting large changes in followers' attitudes, beliefs, and values to the point where organizational goals and vision of leaders are internalized and followers achieve performance above expectations, by playing a role in mentoring, empower and inspire and foster the ability of their followers to contribute to the success of the organization $[27,28]$. Transformational leaders achieve superior results with one or more of the four dimensions of transformational leadership [27], namely: (1) idealized influence (2) inspirational motivation (3) 
intellectual stimulus and (4) individualized consideration.

Transactional leadership style is namely leadership carried out through normative rules and regulations, strict discipline and systematic control with obedience that is built for followers depend on rational values and rules and agreements that are set [29, 30]. There are three dimensions of transaction leadership which are contingent gifts, active management with the exception and passive management with the exception [31].

\subsection{Previous Research}

The leadership style and motivation affected the employee performance [32]. The levels of the relationship between leadership style (X1), motivation (X2), and the provision of incentives (X3) on employee performance (Y) are very strong [13]. The effects of leadership style showed a positive influence on leadership style on employee motivation and performance.

Research on system dynamics implementation in the field of human resource management describes the factors that affect employee performance and different improvement initiatives [33]. Another study examined the use of System Dynamics to Enhance Performance Management in Local Government [34]. The next research examined the modeling of the dynamic performance of a publicly listed construction organization in Malaysia [35].

\subsection{Research Conceptual Framework}

Based on the problems of research and literature, the research conceptual framework can be summarized as follows.

1. The first, influence of transformational and transactional leadership style on motivation and performance.

2. The influence can be examined using SEM and the calculation results can be used to compile a system dynamics simulation to get the expected performance expected through the contribution of the influence of leadership style and motivation through causal loop diagrams, system dynamics modeling, equation modeling and simulation and analysis the results.

Furthermore, the SEM model developed is as follows.

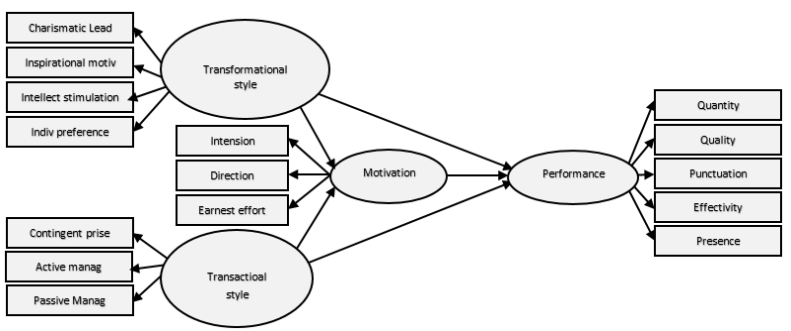

Fig. 1. Conceptual framework of thinking with SEM

Furthermore, based on previous theory and research as well as the conceptual framework of thought compiled with SEM can be arranged causal loop diagrams as follows:

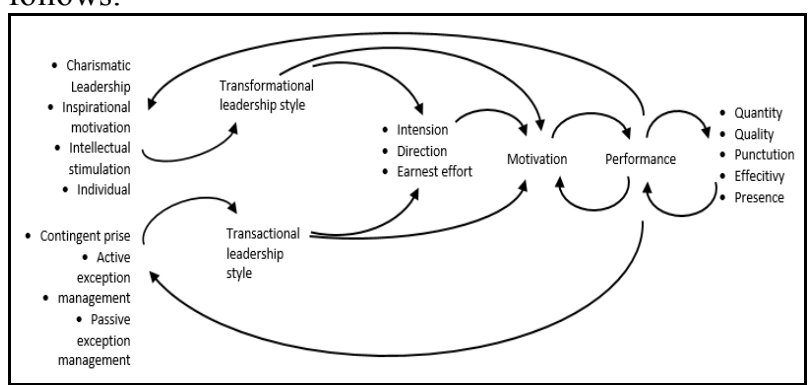

Fig. 2. Causal Loop Diagram of the influence of transformational leadership style and transactional leadership style on the motivation and performance of personnel in military education institutions.

This causal loop diagram will be developed into a system dynamics for the analysis and forecasting process.

\section{Research Methods}

\subsection{Research Place and Time}

This research was carried out within the TNI Educational Institution. When the study was conducted on December 2018.

\subsection{Research Methods}

This research was conducted in two stages. The first step is to find the equation of the regression model with SEM. In this study, four variables were used, namely the exogenous variables of transformational leadership (X1), exogenous variables of transactional leadership (X2), endogenous variables as well as exogenous work motivation (Y1) and endogenous performance variables (Y2). The second stage is estimating and forecasting using system dynamics. Estimates and forecasting are carried out on all four variables with targets to achieve a certain value on the performance variable.

\subsection{Populations and Samples}

The population in this study was all TNI Education Institution personnel. The population of the TNI Educational Institution is 592 people. The sample in this study included 200 TNI personnel. The sample selection was carried out using the proportionate stratified random sampling method [36], namely: each stratum sample size is directly proportional to the population size of the entire population of strata. That means each strata sample has the same sampling fraction.

\subsection{Data Collection Technique}

Data collection techniques are carried out with the following steps.

1. Register all members of the population. All members of the population are listed and coded in 
order of numbers so that they are easily taken as sample points.

2. Determine the sample point. The sample points are obtained from the entire population point at each stratum that has been given a code and randomly drawn with random number tables according to the number of sample points to be selected at each stratum.

3. Provide research instruments in the form of a written questionnaire. Each sample point has been selected according to the strata, given a written questionnaire that needs to be filled in to give his opinion related to the indicators that have been compiled in the statement table by giving a sign $(\sqrt{ })$ in the specified column according to his opinion starting from $1=$ strongly disagree, $2=$ disagree, $3=$ neutral, $4=$ agree, and $5=$ strongly agree.

\subsection{Data Analysis Techniques}

Processing the results of the study was carried out by descriptive statistical analysis to obtain data estimates, each research variable, and values which included data on score, median, mode, standard deviation, and frequency distribution. Furthermore, to test the research hypothesis, inferential statistics were used with Structural Equation Modeling (SEM) with the application of the AMOS program ver 21.0 to obtain the functions of the influence of indicators on exogenous variables and the effect of exogenous variables on endogenous variables. Furthermore, a system dynamics model is developed to describe this in a model. Furthermore, the steps of the research method are carried out as follows:

1. SEM analysis to get the structural equation of the influence of exogenous variables on endogenous and the influence of each dimension and indicator of the dimensions.

2. Compilation of causal loop diagrams

3. Preparation of the System Dynamics model

4. The filling equation in system dynamics uses the results of calculations from SEM

5. Get a table of simulation results and diagrams

6. Perform analysis of results and develop suggestions to improve the value of variables and indicators using the results of calculations.

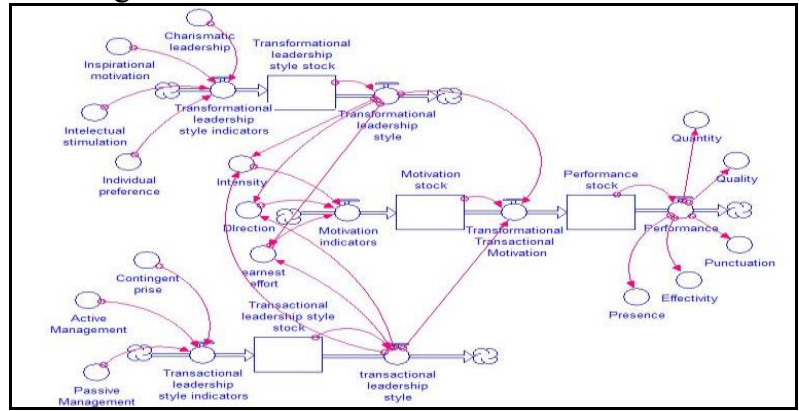

Fig. 3. System dynamics model influences leadership style on the motivation and performance of soldiers.

\section{Analysis Results and Discussion}

\subsection{Overview of Respondents}

This section explains the descriptive analysis obtained from respondents. The research data presented in the form of the number and percentage of respondents of TNI Education Institution personnel according to gender, education, and age. The purpose of the appearance of the description of the respondent's data is to be able to see the respondent's profile and the relationships that exist between the variables used in the study.

In this study, the respondents were the TNI Education Institution Personnel of 200 people, consist of 58 officers, 70 in the Bintara group, and 72 in the Attendance group. Furthermore, the respondents can be detailed and described on their age, gender, and last education. These three descriptions have important roles in the performance within the TNI Education Institution.

\subsection{Data Analysis}

The opinion analysis of respondents was carried out to obtain a description or description of the respondents' opinions especially about the research variables which consisted of 4 variables discussed. This analysis is carried out by using index analysis techniques to describe respondent perceptions of the items asked in each dimension of the variables developed.

Table 1. Results of regression analysis from SEM

\begin{tabular}{|c|c|c|c|}
\hline $\begin{array}{c}\text { Indogen } \\
\text { Variable }\end{array}$ & Regression & $\begin{array}{c}\text { Exogen } \\
\text { variable }\end{array}$ & $\begin{array}{c}\text { Standardized } \\
\text { estimation }\end{array}$ \\
\hline Y1 & $<--$ & $\mathrm{X} 1$ & 0.178 \\
\hline $\mathrm{Y} 1$ & $<--$ & $\mathrm{X} 2$ & 0.822 \\
\hline $\mathrm{Y} 2$ & $<--$ & $\mathrm{X} 1$ & 0.401 \\
\hline $\mathrm{Y} 2$ & $<--$ & $\mathrm{X} 2$ & 0.413 \\
\hline $\mathrm{Y} 2$ & $<--$ & $\mathrm{Y} 1$ & 0.139 \\
\hline $\mathrm{X} 11$ & $<--$ & $\mathrm{X} 1$ & 0.473 \\
\hline $\mathrm{X} 12$ & $<--$ & $\mathrm{X} 1$ & 0.052 \\
\hline $\mathrm{X} 13$ & $<--$ & $\mathrm{X} 1$ & 0.473 \\
\hline $\mathrm{X} 14$ & $<--$ & $\mathrm{X} 1$ & 0.003 \\
\hline $\mathrm{X} 21$ & $<--$ & $\mathrm{X} 2$ & 0.215 \\
\hline $\mathrm{X} 22$ & $<--$ & $\mathrm{X} 2$ & 0.417 \\
\hline $\mathrm{X} 23$ & $<--$ & $\mathrm{X} 2$ & 0.368 \\
\hline $\mathrm{Y} 11$ & $<--$ & $\mathrm{Y} 1$ & 0.460 \\
\hline $\mathrm{Y} 12$ & $<--$ & $\mathrm{Y} 1$ & 0.460 \\
\hline $\mathrm{Y} 13$ & $<--$ & $\mathrm{Y} 1$ & 0.080 \\
\hline $\mathrm{Y} 21$ & $<--$ & $\mathrm{Y} 2$ & 0.715 \\
\hline $\mathrm{Y} 22$ & $<--$ & $\mathrm{Y} 2$ & 0.052 \\
\hline $\mathrm{Y} 23$ & $<--$ & $\mathrm{Y} 2$ & 0.086 \\
\hline $\mathrm{Y} 24$ & $<--$ & $\mathrm{Y} 2$ & 0.097 \\
\hline $\mathrm{Y} 25$ & $<--$ & $\mathrm{Y} 2$ & 0.050 \\
\hline
\end{tabular}

Source: primary data, 2018 
Based on the results of the SEM calculation above, the equation of the functions of the system dynamics model is compiled as follows.

Motivation_stock $(\mathrm{t})=$ Motivation_stock $(\mathrm{t}-\mathrm{dt})+$

(Motivation_indicators -

Transformational_Transactional_Motivation)*dt

INIT Motivation_stock $=$ Motivation_indicators

INFLOWS:

Motivation_indicators $=$

$0.46 *$ DIrection $+0.08 *$ earnest_effort $+0.46 *$ Intensity

OUTFLOWS:

Transformational_Transactional_Motivation $=$

$.139 *$ Motivation_stock $+.413 *$ transactional_leadership_styl e+.403*Transformational_leadership_style

Performance $\operatorname{stock}(\mathrm{t})=$ Performance $\operatorname{stock}(\mathrm{t}-\mathrm{dt})+$

(Transformational_Transactional_Motivation -

Performance) $* \mathrm{dt}$

INIT Performance stock $=$

Transformational_Transactional__Motivation

INFLOWS:

Transformational_Transactional_Motivation $=$

$.139 *$ Motivation_stock $+.413 *$ transactional_leadership_styl

e+.403*Transformational_leadership_style

OUTFLOWS:

Performance $=$ Performance_stock

Transactional_leadership_style_stock $(\mathrm{t})=$

Transactional_leadership_style_stock $(\mathrm{t}-\mathrm{dt})+$

(Transactional_leadership_style_indicators -

transactional_eadership style) ${ }^{*} \mathrm{dt}$

INIT Transactional_leadership_style_stock $=$

Transactional_leadership_style_indicators

INFLOWS:

Transactional_leadership_style_indicators $=$

$0.215 *$ Contingent_prise $+0.417^{*}$ Active_Management +0.36

$8 *$ Passive Management

OUTFLOWS:

transactional_leadership_style $=$

Transactional_leadership_style_stock

Transformational_leadership_style_stock $(\mathrm{t})=$

Transformational__eadership_style_stock $(\mathrm{t}-\mathrm{dt})+$

(Transformational leadership_style indicators -

Transformational_leadership_style) $* \mathrm{dt}$

INIT Transformational leadership style stock $=$

Transformational_leadership_style_indicators

INFLOWS:

Transformational_leadership_style_indicators $=$

$0.473 *$ Charismatic_leadership $+0.052 *$ Inspirational_motiva tion $+0.473 *$ Intelectual_stimulation $+0.003 *$ Individual prefe rence

OUTFLOWS:

Transformational_leadership_style $=$

Transformational_leadership_style_stock

Active_Management $=3.1+$ TIME $^{*} .1$

Charismatic_leadership $=3.1+$ TIME$^{*} .1$

Contingent prise $=3.2+$ TIME$^{*} .1$

DIrection $=$

$3.1+$ TIME$^{*} .1+(.802 *$ transactional leadership_style $+.178 *$

Transformational_leadership_style)*.1

earnest effort $=$

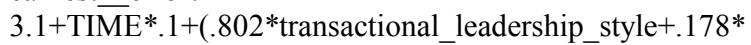

Transformational_leadership_style)*.1

Effectivity $=2.5+\overline{\text { Performance }} .1 * .097$

Individual_preference $=3.1+$ TIME$^{*} .1$

Incnirational motivation $=33+$ TIMF $* 1$
Table 2. System Dynamics Output

\begin{tabular}{|c|c|c|c|c|}
\hline $\begin{array}{c}\text { Tim } \\
\mathrm{e}\end{array}$ & $\begin{array}{c}\text { Transactio } \\
\text { nal } \\
\text { Leadership } \\
\text { Style } \\
\end{array}$ & $\begin{array}{c}\text { Transformatio } \\
\text { nal } \\
\text { Leadership } \\
\text { Style } \\
\end{array}$ & $\begin{array}{c}\text { Motivati } \\
\text { on }\end{array}$ & $\begin{array}{c}\text { Performan } \\
\text { ce }\end{array}$ \\
\hline 0 & 3.12 & 3.26 & 3.22 & 3.05 \\
\hline 0.5 & 3.17 & 3.31 & 3.25 & 3.05 \\
\hline 1 & 3.22 & 3.36 & 3.29 & 3.06 \\
\hline 1.5 & 3.27 & 3.41 & 3.33 & 3.08 \\
\hline 2 & 3.32 & 3.46 & 3.36 & 3.12 \\
\hline 2.5 & 3.37 & 3.51 & 3.4 & 3.15 \\
\hline 3 & 3.42 & 3.56 & 3.44 & 3.2 \\
\hline 3.5 & 3.47 & 3.61 & 3.48 & 3.24 \\
\hline 4 & 3.52 & 3.66 & 3.51 & 3.29 \\
\hline 4.5 & 3.57 & 3.71 & 3.55 & 3.34 \\
\hline 5 & 3.62 & 3.76 & 3.59 & 3.39 \\
\hline 5.5 & 3.67 & 3.81 & 3.63 & 3.44 \\
\hline 6 & 3.72 & 3.86 & 3.67 & 3.49 \\
\hline 6.5 & 3.77 & 3.91 & 3.71 & 3.53 \\
\hline 7 & 3.82 & 3.96 & 3.75 & 3.58 \\
\hline 7.5 & 3.87 & 4.01 & 3.79 & 3.63 \\
\hline 8 & 3.92 & 4.06 & 3.83 & 3.67 \\
\hline 8.5 & 3.97 & 4.11 & 3.87 & 3.72 \\
\hline 9 & 4.02 & 4.16 & 3.91 & 3.76 \\
\hline 9.5 & 4.07 & 4.21 & 3.95 & 3.81 \\
\hline 10 & 4.12 & 4.26 & 3.99 & 3.85 \\
\hline 10.5 & 4.17 & 4.31 & 4.03 & 3.9 \\
\hline 11 & 4.22 & 4.36 & 4.07 & 3.94 \\
\hline 11.5 & 4.27 & 4.41 & 4.11 & 3.99 \\
\hline 12 & 4.32 & 4.46 & 4.15 & 4.04 \\
\hline
\end{tabular}

Source: primary data, 2018

Based on system dynamics output data in Table 2, it can be arranged graphically on one graph. It is important to show the output that graphically compares all variable changes in accordance with changes in simulation time. The output of the graph is presented in Fig. 4.

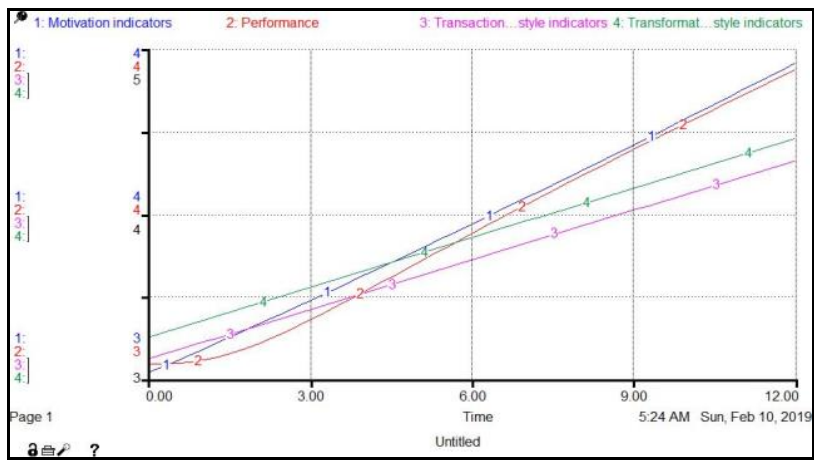

Fig. 4. Transformational leadership style, transactional leadership style, motivation, and performance graph 
Based on the data in Table 2, several important points can be drawn up to explain. The important points used are the starting point, midpoint and endpoint of the four variables. More information is presented in Table 3 .

Table 3. Resume of system dynamics' simulation

\begin{tabular}{|c|c|c|c|c|}
\hline Time & $\begin{array}{c}\text { Transactional } \\
\text { Leadership } \\
\text { Style }\end{array}$ & $\begin{array}{c}\text { Transforma- } \\
\text { tional } \\
\text { Leadership } \\
\text { Style }\end{array}$ & Motivation & Performance \\
\hline 0 & 3.12 & 3.26 & 3.22 & 3.05 \\
\hline 6 & 3.72 & 3.86 & 3.67 & 3.49 \\
\hline 12 & 4.32 & 4.46 & 4.15 & 4.04 \\
\hline
\end{tabular}

Source: Primary data, 2018

From the initial conditions, it corresponds to the average of each variable, namely the transactional leadership style of 3.12 ; transformational leadership style of 3.26 ; motivation of 3.22 ; and performance of 3.05. Next is a simulation based on the system dynamics model that has been compiled and the equation that has been compiled based on the results of SEM analysis, then after time $=6$ a change in transactional leadership style is obtained to 3.72 ; transformational leadership style to 3.86 ; motivation becomes 3.67 ; and performance to 3.49 . Whereas after time $=12$, data was obtained that the transactional leadership style became 4.32; transformational leadership style to 4.46 ; motivation becomes 4.15; and the performance becomes 4.04.

Thus, to increase performance from 3.05 to 4.04 (.99 points), an increase in the transactional leadership style is needed from 3.12 to 4.32 (1.2 points), transformational leadership style from 3.26 to 4.46 (1.2 points) and motivation 3.22 to 4.15 (.93 points). This is an increase in the increase in transactional leadership style, transformational leadership style, and motivation that must be sought to get an increase in performance as expected.

\section{Conclusion and Implication of Policies}

\subsection{Conclusion}

Based on the hypothesis proposed in this study and the results of the analysis that has been carried out using data from respondents from the TNI Educational Institution personnel that were processed and analyzed using SEM and continued with system dynamics, can be concluded that transformational leadership style, transactional leadership style and motivation have a significant positive effect on the performance of personnel in the TNI Educational Institution. Furthermore, system dynamics can be used to model the effect of transformational leadership style, transactional leadership style, and motivation that have a positive significant effect on personnel performance using regression equations resulting from SEM analysis. The estimated results of forecasting are to improve performance from 3.05 to 4.04 (.99 points), it is necessary to increase the transactional leadership style from 3.12 to 4.32 (1.2 points), transformational leadership style from 3.26 to 4.46 (1.2 points) and motivation 3.22 to 4.15 (. 93 points). These points show that it is needed to increase the transactional leadership style, transformational leadership style and motivation in order to increase the performance as expected.

\subsection{Policy Implications}

Referring to the hypothesis and the results of the analysis that have proven the hypothesis, it can be conveyed some suggested policy implications for the TNI Education Institution, especially in an effort to optimize personnel performance using three predictor variables namely transformational leadership style, transactional leadership style, and work motivation. Based on the results of testing, all three had a positive effect on the performance of personnel in the TNI Educational Institution. With the level of influence from the highest to the lowest, each of them is work motivation, transactional leadership style, and transformational leadership style. In connection with this, the TNI Educational Institution can pay particular attention to improved performance that is expected to be obtained by increasing the transactional leadership style, increasing the transformational leadership style, and increasing motivation. Besides this, increasing transformational leadership styles that can provide support for improved performance can be pursued through improving the dimensions of charismatic leadership, inspirational motivation, intellectual stimulation, and individual preferences. And, increased transactional leadership style in TNI Education Institutions that can provide support for improved performance, can be pursued through efforts to increase the dimensions of contingent gifts, active exception management, and passive exception management. The last, increase in work motivation that is expected in improving the performance of personnel in the TNI Education Institute includes efforts to increase the dimensions of intensity, direction, and earnest effort.

\section{References}

1. F. Cavazotte, V. Moreno, J. Bernardo, Transformational Leaders and Work Performance: The Mediating Roles of Identification and Selfefficacy, BAR, Rio de Janeiro 10 (4) art. 6, 490-512 (2013)

2. K. Elgelal, Noermijati, The Infuences of Transformational Leaderships on Employees Performance (A Study of the Economics and Business Faculty Employee at University of Muhammadiyah Malang). Asia Pacific Management and Business Application 3 (1), 48-66 (2014)

3. S.N. Mottoh. The Influence of Transformational and Transactional Leadership Style on Employee Performance (Case Study: Dinas Kesehatan Manado), Jurnal Berkala Ilmiah Efisiensi 15 (04) (2015) 
4. A. Advani, Z. Abbas, Impact of Transformational and Transactional Leadership Styles on Employees' Performance of Banking Sector in Pakistan, Global Journal of Management and Business Research: an Administration and Management 15 Issue 5 Version $1.0(2015)$

5. A.H. Aunjum, G. Abbas, M. Sajid, Transformational Leadership and Employee Motivation in Banking Sector of Pakistan, Advances in Economics and Business 5 (9), 487-494 (2017)

6. R. Gopal, R.G. Chowdhury, Leadership Styles and Employee Motivation: An Empirical Investigation in a Leading Oil Company in India. IMPACT: International Journal of Research in Business Management (IMPACT: IJRBM) ISSN (E): 2321886x; ISSN (P): 2347-4572 2 (5), 1-10 (2014)

7. A.Q. Chaudhry, H. Javed, M. Sabir, The Impact of Transformational and Transactional Leadership Styles on the Motivation of Employees in Pakistan, Pakistan Economic and Social Review 50 (2), 223231 (2012)

8. S.P. Robbins, Organizational Behavior 13th Edition. Pearson Education Inc, Prentice Hall (2006)

9. S.R. Bhatti, S. Haidar, The Impact of Employees' Motivation on Performance: Findings from Karachi Based Service Organization. IJMS 2 (1) (2014)

10. Ghaffari, et al, The Influence of Motivation on Job Performance: A Case Study at Universiti Teknologi Malaysia, Australian Journal of Basic and Applied Sciences 11 (4), 92-99 (2017)

11. Marnis. Transformational Leadership in the Efforts of Increasing Motivation, Performance, and Job Satisfactions at Pt Bank Mandiri Tbk. Journal of Economics, Business, And Accountancy Ventura 15 (2), $273-288$ (2012)

12. K. Sundi, Effect of Transformational Leadership and Transactional Leadership on Employee Performance of Konawe Education Department at Southeast Sulawesi Province, International Journal of Business and Management Invention ISSN (Online): 2319 - 8028, ISSN (Print): 2319 - 801X 2(12), 50-58 (2013)

13. Elqadri, Priyono, P. Suci, Chandra, Effect of Leadership Style, Motivation, and Giving Incentives on the Performance of Employees-PT. Kurnia Wijaya Various Industries. International Education Studies 8 (10) ISSN 1913-9020 E-ISSN 1913-9039 (2015)

14. M.J. Radzicki, R.A. Taylor, Origin of System Dynamics: Jay W. Forrester and The History of System Dynamics, US Department of Energy's Introduction to System Dynamics (2008)

15. J. Sterman, R. Oliva, K. Linderman, E. Bendoly, System Dynamics perspectives and modeling opportunities for research in Operations Management, Journal of Operations Management, 39-40:1-5 (2015)

16. C.M. Stein, N.N. Nora, Structural Equation Modelling. Methods in molecular biology (Clifton, N.J.). 850. 495-512. 10.1007/978-1-61779-555-8_27 (2012)
17. E. Suryani, S.Y. Chou, C.H. Chen, Dynamic simulation model of air cargo demand forecast and terminal capacity planning, Simulation Modelling Practice and Theory 28, 27-41 (2012)

18. J.P. Campbell, Modeling the performance prediction problem in industrial and organizational psychology. Handbook of Industrial and Organizational Psychology, 687-732 (1990)

19. D. Hellriegel, S.E. Jackson, J.W. Slocum, Management. New York: Addison Wesley (1999)

20. R.L. Mathis, J.H. Jackson, Human Resource Management, Jakarta: Salemba Empat (2006)

21. J.R. Schermerhorn. Management (8 ed), New York : John Wiley and Sons Inc (2005)

22. M. Korth, Maslow - Move Aside! A Heuristical Motivation Model for Leaders in Career and Technical Education, Journal of Industrial Teacher Education, 5-36 (2007)

23. J.M. George, G.R. Jones, Understanding and Managing Organizational behavior (5 ed), Pearson/Prentice Hall New Yersey, 78 (2008)

24. S.P. Robbins, T.A. Judge, Organizational Behavior (14 ed), Pearson Education New Jersey (2011)

25. M. Chemers, An Integrative Theory of Leadership. New York: Psychology Press (2014)

26. T.S. Nanjundeswaraswamy, D.R. Swamy, Leadership styles. Advances in Management 7 (2) (2014)

27. A.R. Gomes, Transformational leadership: Theory, research, and application to sports. In C. Mohiyeddini (Ed.), Contemporary topics and trends in the psychology of sports, New York: Nova Science Publishers, 53-114 (2014)

28. S. Harper, The Leader Coach: A Model of MultiStyle Leadership, Journal of Practical Consulting 4 (1), 22-31 (2012)

29. G. Yukl, Leadership in organisations (6th ed). London: Prentice Hall (2006)

30. J.M. Burns, Leadership, New York: Harper \& Row (2010)

31. O. Folakemi, A. Anthonia, A.I. Dayo, Human Resource Management Practices and Organisational Commitment: Employees' Perspective in the Nigerian Hospitality Sector. New Trends and Issues Proceedings on Humanities and Social Sciences 4 (10), 246-255 (2017)

32. R. Mehta, A.J. Dubinsky, R.E. Anderson, Leadership Style, Motivation and Performance in International Marketing Channels: An Empirical Investigation of the USA, Finland and Poland. European Journal of Marketing 37, 50-85 (2003)

33. M. Alefari, A.M.F. Barahona, K. Salonitis, Modelling Manufacturing Employees' Performance Based on A System Dynamics Approach. Procedia CIRP 72, 438-443 (2018)

34. C. Bianchi, W.C. Rivenbark, Using System Dynamics to Enhance Performance Management in Local Government: An Application to Residential Refuse Collection, Paper presented at the 2012 APPAM Fall Research Conference, 8-10 (2012)

35. Y.H. Tang, S.O. Ogunlana, Modelling The Dynamic Performance of $A$ Construction 
Organization, Construction Management and Economics 21(2), 127-136_(2003)

36. A. Bhat, Stratified Random Sampling: Definition, Method And Examples, (2018) 